\title{
PRODUCTION AND QUALITY OF Anacardium othonianum Rizz. SEEDLINGS GROWN IN DIFFERENT SUBSTRATES ${ }^{1}$
}

\author{
PAULO DORNELLES ${ }^{2}$, FABIANO GUIMARÃES SILVA ${ }^{3}$, \\ CLENILSO SEHNEN MOTA4 ${ }^{4}$, JOÃO DAS GRAÇAS SANTANA ${ }^{3}$
}

\begin{abstract}
This study aimed to evaluate the effect of substrate on growth, emergence, nutrition, and quality of Anacardium othonianum Rizz. (cerrado cashew tree) seedlings. The experiment was conducted in a greenhouse at the Plant Tissue Culture Laboratory on the Rio Verde campus. The following substrates were used: 1) Bioplant $\left.{ }^{\circledR}, 2\right)$ Mecplant $^{\circledR}(\mathrm{MP})+$ carbonized rice husk (CRH) $(7: 3)$, 3) fine-grained vermiculite (FGV), 4) FGV+CRH $(3: 1), 5) \mathrm{FGV}+\mathrm{CRH}(1: 1), 6) \mathrm{FGV}+\mathrm{CRH}(1: 3)$, and 7) sugarcane bagasse (SB) + sugarcane mill filter cake (FC) (3:2). Emerged seedlings were counted at 2-day intervals for 38 days following emergence of the first seedling. At 39, 64, and 89 days after seeding (DAS), the following variables were measured: stem length (SL), stem diameter (SD), and number of leaves (NL). Accumulated dry weight, quality indices, and leaf macro- and micronutrient levels were determined at 89 DAS. Plants grown in the FGV and $\mathrm{FGV}+\mathrm{CFH}(1: 3)$ substrates had shorter stem lengths than the plants grown in other substrates. Increases in seedling growth were smaller between 64 and 89 DAS compared to the initial period of the experiment. The highest leaf $\mathrm{N}$ concentrations were found in the $\mathrm{SB}+\mathrm{FC}$ substrate treatment group; $\mathrm{P}$ and $\mathrm{K}$ concentrations were higher for the $\mathrm{MP}+\mathrm{CRH}(7: 3), \mathrm{SB}+\mathrm{FC}$, and Bioplant ${ }^{\circledR}$ treatments; and $\mathrm{Ca}$ levels were higher for the $\mathrm{SB}+\mathrm{FC}$ and $\mathrm{MP}+\mathrm{CRH}(7: 3)$ substrate treatments. The MP+CRH (7:3) substrate treatment group had the highest leaf $\mathrm{B}$ and $\mathrm{Mn}$ micronutrient concentrations, and plants from the Bioplant ${ }^{\mathbb{B}}$ substrate group had the highest leaf B micronutrient content. $\mathrm{Mg}, \mathrm{S}, \mathrm{Cu}, \mathrm{Zn}$, and Fe concentrations did not differ among the different substrates. The plant traits that differed most among the treatments included stem length for the FGV and $\mathrm{FGV}+\mathrm{CRH}(1: 3)$ substrate groups and leaf nutrient concentrations, which were higher for the SB+FC group followed by the $\mathrm{MP}+\mathrm{CRH}$ and Bioplant ${ }^{\circledR}$ treatments.
\end{abstract}

Index terms: cerrado cashew tree, seedling growth, seedling nutrition, substrates.

\section{PRODUÇÃO E QUALIDADE DE MUDAS DE Anacardium othonianum Rizz. EM DIFERENTES SUBSTRATOS}

RESUMO- Este trabalho teve como objetivo avaliar o efeito de diferentes tipos de substratos no crescimento e na nutrição, e a qualidade de mudas de caju-de-árvore-do-cerrado. O experimento ocorreu em casa de vegetação. Os substratos utilizados foram: 1- Bioplant ${ }^{\mathbb{\circledR}} ; 2$ - Mecplant ${ }^{\circledR}(\mathrm{MP})+$ casca de arroz carbonizada (CAC) (7:3); 3- vermiculita de granulometria fina (VGF); 4- VGF+CAC (3:1); 5- VGF+CAC (1:1); 6VGF+CAC (1:3) e 7- Bagaço de cana-de-açúcar (BC) + torta de filtro de usina de cana-de-açúcar (TF) (3:2). A contagem das plântulas emergidas foi realizada em intervalos de dois dias após a emergência da primeira plântula. Aos 39; 64 e 89 dias após a semeadura (DAS), avaliaram-se o comprimento do caule (CC), o diâmetro do coleto (DC) e o número de folhas (NF). O acúmulo de massas secas, índices de qualidade e concentração foliar de macro e micronutrientes foram avaliados aos 89 DAS. Plantas desenvolvidas nos substratos VGF e VGF+CAC (1:3) apresentaram os menores CC em relação aos demais. O incremento no crescimento foi menor entre os 64 e 89 DAS, em relação ao primeiro intervalo. A maior concentração foliar de $\mathrm{N}$ foi observada no substrato $\mathrm{BC}+\mathrm{TF}$, de $\mathrm{P}$ e $\mathrm{K}$ em MP+CAC (7:3), BC+TF e Bioplant ${ }^{\circledR}$ e Ca no $\mathrm{BC}+\mathrm{TF}$ e MP+CAC (7:3). Já para os micronutrientes B e Mn, o substrato MP+CAC (7:3) apresentou as maiores concentrações foliares, juntamente com o Bioplant ${ }^{\mathbb{R}}$ para o elemento B. As concentrações de $\mathrm{Mg}$, $\mathrm{S}, \mathrm{Cu}, \mathrm{Zn}$ e $\mathrm{Fe}$ não apresentaram diferenças. A característica a diferir as mudas cultivadas nos substratos foi a concentração foliar dos nutrientes, tendo destaque o $\mathrm{BC}+\mathrm{TF}$ seguido pelo $\mathrm{MP}+\mathrm{CAC}$ e Bioplant ${ }^{\mathbb{}}$.

Termos para indexação: Caju-de-árvore-do-cerrado, qualidade de mudas, nutrição de mudas, substratos.

${ }^{1}$ (Trabalho 144-13). Recebido em:04-04-2013. Aceito para publicação em: 28-02-2014.

${ }^{2}$ Master, Instituto Federal Goiano, Câmpus Rio Verde, GO, Brasil, Rod. Sul Goiana km 1, cx.p. 66, CEP 75901- 970. E-mail: dornellesifgoiano@gmail.com

${ }^{3}$ Professor PhD, Instituto Federal Goiano- Câmpus Rio Verde. E-mail: fabianoifgoiano@gmail.com; jgsantana1@bol.com.br ${ }^{4}$ D.Sc., Programa Nacional de Pós-Doutorado/Coordenação de Aperfeiçoamento de Pessoal de Nível Superior (PNPD/CAPES). E-mail: csm.sehnen@gmail.com 


\section{INTRODUCTION}

Anacardium othonianum Rizz. is an important native fruit tree of the Brazilian cerrado biome (Brazilian savannah), both for food and for the medicinal properties of its fruit, pseudo fruit, bark, leaves, and flowers. On average, A. othonianum trees are 3 to $4 \mathrm{~m}$ tall and have elliptical, coriaceous, and glabrous leaves. The bracts are leafy and hairy, with narrow, elongated, and reddish petals. The male flowers bloom at the onset of the flowering phase, while the hermaphrodites emerge near the final stages of flowering and are pollinated by bees and wasps (CORREA et al., 2008).

The pseudo fruit of $A$. othonianum varies in size and color, and there are 200-600 pseudo fruit per plant. The pseudo fruit is consumed fresh or processed into sweets, jellies, liqueurs, juices, ice cream, popsicles, candied fruit, and other products. Roasted and peeled, the achene (true fruit) is considered a valuable delicacy for its taste and texture. The fruit and pseudo fruit are rich in energy, carbohydrates, lipids, proteins, minerals, and vitamins (SILVA et al., 2008).

In recent years there has been increasing interest and demand for seedlings of native cerrado species by farmers and businesses (SOUZA et al., 2007) in response to changes in economic markets, environmental awareness, and government regulations. For the implementation of commercial orchards or reforestation projects to be successful, it is necessary to use healthy and high-quality seedlings at the nursery stage (ROSA et al., 2005).Seedling quality is evaluated using the following indices: the shoot to root dry weight ratio $(\mathrm{R} / \mathrm{S})$, i.e., the ratio of the weight of the roots of a seedling to the weight of the shoot; the stem length to stem diameter ratio (SL/ $\mathrm{SD})$, which is a measure of robust ness and indicates the degree of etiolate on the seedling; and the quality index created by Dickson et al. (1960), which is a complete index that accounts for total seedling dry weight in addition to R/S and SL/SD.

Substrate quality is a major factor affecting seedling quality. A substrate must adequately meet plant requirements in terms of its physical and chemical attributes because it acts as a substitute for soil during the nursery stage (FERRAZ et al., 2005).A high-quality substrate is determined by the following factors: for root system maintenance, the substrate must be in a container large enough to accommodate the seedling and allow it to have adequate porosity; the substrate itself must have a slow decomposition rate and high cation exchange capacity; it must be pathogen-free and free of additional undesirable plant seeds; and it must be available on the market at a competitive price (DANTAS et al., 2009).To meet these requirements, it is necessary to mix two or more components that have desirable attributes to create a good substrate for seedling production (ARAÚJO NETO et al., 2009).

The need to eliminate or reuse increasing amounts of agro-industrial residues to reduce consumption of non-renewable resources has encouraged studies on alternative materials (GRIGATTI et al., 2007) such as sugarcane bagasse and filter cake from sugarcane mills (CATUNDA et al., 2008; SANTANA et al., 2012) as well as carbonized rice husks (SAIDELLES et al., 2009; TERRA et al., 2011) as substrates for seedling production and horticultural use. The use of raw materials that are easily found near seedling nurseries is also preferred. However, there are few or no studies on the use of agro-industrial residues as substrates for native cerrado species. Therefore, this study aimed to evaluate the effects of different substrates on emergence, growth, nutrition, and quality of Anacardium othonianum Rizz. seedlings.

\section{MATERIALS AND METHODS}

The experiment was conducted in a greenhouse at the Plant Tissue Culture Laboratory of the Goiano Federal Institute (Instituto Federal Goiano) on the Rio Verde campus ( $17^{\circ} 48^{\prime} 16^{\prime}$ S, 50 54' 19” W, $749 \mathrm{~m}$ altitude). Anacardium othonianum fruit used for the experimental plantings was harvested from plants growing naturally at the Gameleira Farming in the municipality of Montes Claros de Goiás, GO, Brazil (16 06' 20" S, 51 17 ' 11" W, 592 m altitude). A voucher specimen (Anacardium othonianum Rizz., No. 3793) was deposited at the Jataiense Herbarium (Herbário Jataiense) at the Federal University of Goiás (Universidade Federal de Goiás), Jataí campus. After collection, the fruit was taken to the laboratory where the seeds (achenes) were separated from the pulp (pseudo fruit). The damaged seeds were discarded, and the seeds selected for the study were treated, dried, and stored according to Assis et al. (2012).

The following raw materials were used in the substrates: Bioplant ${ }^{\circledR}$, Mecplant ${ }^{\circledR}(\mathrm{MP})$, carbonized rice husk $(\mathrm{CRH})$, fine-grained vermiculite (FGV), sugarcane bagasse (SB), and sugarcane mill filter cake (FC) from the Nova Gália sugarcane mill in Acreúna, GO, Brazil. The SB was crushed and sieved through 10-mm mesh, and the FC was sieved through 5-mm mesh. The following substrates were used in the experiment (all ratios are in $\mathrm{v} \mathrm{v}^{-1}$ ): 1) Bioplant $\mathrm{t}^{\circledR}$, 
2) $\mathrm{MP}+\mathrm{CRH}(7: 3), 3) \mathrm{FGV}$, 4) FGV+CRH $(3: 1), 5)$ $\mathrm{FGV}+\mathrm{CRH}(1: 1), 6) \mathrm{FGV}+\mathrm{CRH}(1: 3)$, and 7) SB+FC (3:2). After preparation of the substrates, samples of each substrate were collected for determining available water and total porosity according to Fermino et al. (2010).

For the experiment, $288-\mathrm{cm}^{3}$ test tubes were filled completely with substrate. One seed was sown per test tube, and the tubes were kept in greenhouse under white screen netting that allowed 15\% solar irradiance to reach the tubes. Irrigation was applied by spraying twice daily (8:30 am and 4:30 pm) with $12 \mathrm{~mm}$ of total daily volume. Temperature and relative humidity inside the greenhouse were recorded with a LAGBOX-RHT-LCD Data Logger (NOVUS, Porto Alegre, Brazil). A mean temperature of $21.6^{\circ} \mathrm{C}$ and $74 \%$ mean relative humidity were maintained throughout the experiment.

Seedling emergence was recorded every 2 days for 38 days beginning with the day that the first emergence was observed. Each day, the total number of emerged seedlings was recorded, and the emerged seedling percentage (ESP), viable seedling percentage (VSP), and emergence rate index (ERI) were calculated according to Maguire (1962). The following variables were recorded at 39, 64, and 89 days after seeding (DAS): stem length (SL), stem diameter (SD), number of leaves (NL), and stem length to stem diameter ratio (SL/SD). Leaf area (LA) was measured at 89 DAS with visualized leaf images using imaging software. Following the measurement of leaf area at $89 \mathrm{DAS}$, the plants were separated into stems, leaves, and roots and dried in a forced-air oven at $65^{\circ} \mathrm{C}$ to a constant weight to obtain dry weights. After obtaining the dry weights for stems, leaves, and roots, the root to shoot ratio $(\mathrm{R} / \mathrm{S})$ and the Dickson quality index (DQI) were calculated (DICKSON et al., 1960). The dried leaves were ground in a Willey mill, and $\mathrm{N}, \mathrm{P}, \mathrm{K}, \mathrm{Ca}, \mathrm{Mg}, \mathrm{S}, \mathrm{Fe}, \mathrm{B}, \mathrm{Cu}, \mathrm{Zn}$, and Mn concentrations were determined according to methods described by Malavolta et al. (1997).

Physical properties of the substrates were evaluated in the Soil Physics Laboratory according to a completely randomized design with six replications. For the greenhouse evaluations (ESP, VSP, and ERI), a randomized block design with five replications and 20 test tubes per replication was used. Growth, nutrition, and quality of seedlings were sampled using a randomized block design with four replications and seven test tubes per replication in a split plot arrangement. The plots were substrates, and the sub-plots were the temporal periods for evaluating SL, SD, SL/SD, and NL. The other variables, including available water (AW), total porosity (TP), leaf dry weight (LDW), stem dry weight (SDW), total dry weight (TDW), R/S, DQI, and macro- and micronutrient leaf concentrations, were analyzed in blocks. An analysis of variance (ANOVA) was performed on the data, and the means were compared with Tukey's test at a 5\% significance level using SISVAR software (FERREIRA, 2011).

\section{RESULTS AND DISCUSSION}

The ESP, VSP, and ERI of the seedlings did not differ among the substrates used in the experiment, with mean values of $79 \%, 76 \%$, and 0.72 , respectively (Table 1 ). According to Nogueira et al. (2003), to promote germination and emergence, a substrate must have sufficient porosity to allow seed aeration and hydration. The seeds do not need nutrients to germinate and emerge, but they do need oxygen and water for cell metabolism. Silva et al. (2009) found that a higher ERI was associated with light and porous substrates with high drainage capacity, which facilitates oxygenation. Although there were not significant Pearson's correlations between the substrates in this experiment and seedling emergence or ERI, the substrates differed in terms of total porosity (TP) and available water (AW). The Bioplant ${ }^{\circledR}$ and FGV substrates had the highest TP with a mean TP of $0.75 \mathrm{~m}^{3} \mathrm{~m}^{-3}$, while the highest available water content was recorded in the Bioplant ${ }^{\circledR}$ substrate at $0.24 \mathrm{~m}^{3} \mathrm{~m}^{-3}$ (Table 2). The lowest AW and TP values were observed in the FGV+CRH substrate $(1: 3)$ at 0.02 and $0.48 \mathrm{~m}^{3} \mathrm{~m}^{-3}$, respectively.However, all substrates had TP values below $0.85 \mathrm{~m}^{3} \mathrm{~m}^{-3}$, as suggested by De Boodt et al. (1974).

The results for $\mathrm{SL}, \mathrm{SD}, \mathrm{SL} / \mathrm{SD}$, and NL showed no significant interaction between sampling period and substrate, and therefore, these variables were analyzed individually. The highest increases in SL, SD, SL/SD, and NL occurred during first two periods of evaluation in comparison to the third period, whereas increases in DC were similar between all three periods (Table 3 ). There was a tendency for stabilization in these variables over the duration of the experiment, possibly as a result of reduced nutrient availability in the substrate and lack of space for root development. The space restriction for the growth and development of root causes morphological changes in the root system these changes reflected in the shoot, one of the changes reduced shoot growth (MATHERS et al., 2007).

At 89 DAS, SL was higher in the Bioplant ${ }^{\circledR}$, $\mathrm{MP}+\mathrm{CRH}, \mathrm{SB}+\mathrm{FC}, \mathrm{FGV}+\mathrm{CRH}(3: 1)$, and FGV+CRH $(1: 1)$ substrates than in the remaining substrates. The 
other seedling growth attributes, SD, NL, LA, LDW, SDW, root dry weight (RDW), and TDW, were not affected by substrate (Table 4). According to Gomes et al. (2002),stem length is a good parameter for assessing seedling quality because it can be measured easily and non-destructively. The results of this study suggest that the FGV and FGV+CRH (1:3) substrates produced lower quality seedlings than the other substrates because there were no differences in plant $\mathrm{R} / \mathrm{S}, \mathrm{SL} / \mathrm{SD}$, or DQI among the different substrates (Table 5). It is shown that with this substrate did not affect the quality of seedlings, as well as the growth characteristics, thus demonstrating that the plant Anacardium othonianum adapted to different substrates studied.

Leaf concentrations of $\mathrm{Mg}, \mathrm{S}, \mathrm{Fe}, \mathrm{Cu}$, and $\mathrm{Zn}$ did not differ among the treatments. The highest leaf $\mathrm{N}$ concentrations were found in the plants grown in $\mathrm{SB}+\mathrm{FC}$ (Table 6). Plants grown in the MP+CRH and Bioplant ${ }^{\mathbb{B}}$ substrates, in addition to plants grown in $\mathrm{SB}+\mathrm{FC}$, had higher leaf levels of $\mathrm{P}$ and $\mathrm{K}$, whereas plants grown in $\mathrm{SB}+\mathrm{FC}$ and $\mathrm{MP}+\mathrm{CRH}$ had higher levels of $\mathrm{Ca}$. Plants grown in $\mathrm{MP}+\mathrm{CRH}$ had the highest leaf concentrations of the micronutrients $\mathrm{Mn}$ and $\mathrm{B}$, together with the plants grown in Bioplant ${ }^{\mathbb{B}}$ for the micronutrient $\mathrm{B}$ (Table 7). The highest leaf levels of $\mathrm{N}, \mathrm{K}, \mathrm{P}, \mathrm{Ca}, \mathrm{B}$, and $\mathrm{Mn}$ were observed in plants grown in the $\mathrm{SB}+\mathrm{FC}$, Bioplant ${ }^{\circledR}$, and $\mathrm{MP}+\mathrm{CRH}$ substrates. The high levels of nutrients in these plants are likely due to the fertilizer that is added to commercial substrates (according to information from the manufacturer). Additionally, the $\mathrm{SB}+\mathrm{FC}$ substrate contained approximately $40 \%$ sugarcane filter cake, which is often used as organic fertilizer (FIDALSKI and CHAVES, 2010; SANTANA et al., 2012).

Due to the difficulty of finding previously published data for leaf nutrient levels to compare with the results of this study, the results were compared to those reported by Crisóstomo and Naumov (2009) for Anacardium occidentale L. in Brazil. Of the micronutrients measured in the present study, only $\mathrm{Zn}$ was found at adequate levels for plant growth in all of the substrates, and adequate $\mathrm{Mn}$ concentrations were only found in plants grown in $\mathrm{MP}+\mathrm{CRH}$. Fe was the only nutrient found at levels above the range suitable for plants, and the observed levels may have even been toxic. Leaf concentrations of $\mathrm{B}$ and $\mathrm{Cu}$ in the Anacardium othonianum Rizz. seedlings grown in all substrates were lower than in the concentrations found in A. occidentale L. (CRISÓSTOMO and NAUMOV, 2009). The macronutrient concentrations (N, P, K, $\mathrm{Ca}, \mathrm{Mg}$, and $\mathrm{S}$ ) were within or near appropriate ranges for the cashew plant (A. occidentale $\mathrm{L}$.). In the present study, the most desirable nutrient levels were found in plants grown in the $\mathrm{SB}+\mathrm{FC}, \mathrm{MP}+\mathrm{CRH}$, and Bioplant ${ }^{\circledR}$ substrates, while stem diameter was lowest in the plants grown in the FGV and FGV+CRH (1:3) substrates.

TABLE 1- Emerged seedling percentage (ESP), viable seedling percentage (VSP), and emergence rate index (ERI) for Anacardium othonianum Rizz. Plants grown on different substrates.

\begin{tabular}{lccc}
\hline Substrate & ESP (\%) & VSP (\%) & ERI \\
\hline Bioplant ${ }^{\circledR}$ & $84 \pm 5.1^{\mathrm{y}}$ & $81 \pm 4.8^{\mathrm{y}}$ & $0.76 \pm 0.29^{\mathrm{y}}$ \\
MP $^{\mathrm{x}}+\mathrm{CRH}^{\mathrm{w}}(7: 3)$ & $78 \pm 3.0$ & $77 \pm 3.4$ & $0.78 \pm 0.24$ \\
FGV $^{\mathrm{v}}$ & $79 \pm 5.1$ & $79 \pm 5.1$ & $0.74 \pm 0.27$ \\
FGV + CRH $(3: 1)$ & $73 \pm 2.0$ & $68 \pm 1.2$ & $0.69 \pm 0.23$ \\
FGV+CRH (1:1) & $80 \pm 2.7$ & $74 \pm 5.1$ & $0.71 \pm 0.19$ \\
FGV+CRH (1:3) & $78 \pm 5.8$ & $76 \pm 5.3$ & $0.62 \pm 0.12$ \\
SB $^{\mathrm{u}}+\mathrm{FC}^{\mathrm{t}}(3: 2)$ & $80 \pm 2.7$ & $77 \pm 4.4$ & $0.77 \pm 0.19$
\end{tabular}

${ }^{\mathrm{y}}$ Means $\left( \pm\right.$ standard error) are not significantly different according to a Tukey’s test $(\mathrm{p}<0.05) .{ }^{\mathrm{x}}$ Mecplant ${ }^{\mathbb{\mathbb { }}}$; ${ }^{ }$Carbonized rice husk;

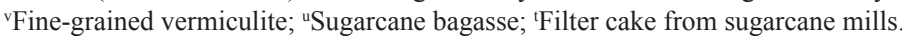


TABLE 2 - Available water (AW) and total porosity (TP) of substrates used for Anacardium othonianum Rizz. seedling production.

\begin{tabular}{lcc}
\hline \multirow{2}{*}{ Substrate } & \multicolumn{1}{c}{ AW } & TP \\
\cline { 2 - 3 } & \multicolumn{2}{c}{$\mathrm{m}^{3} \mathrm{~m}^{-3}$} \\
\hline Bioplant $^{\circledR}$ & $0.24 \pm 0.01 \mathrm{a}^{\mathrm{z}}$ & $0.74 \pm 0.02 \mathrm{a}^{\mathrm{z}}$ \\
MP $^{\mathrm{x}}+\mathrm{CRH}^{\mathrm{w}}(7: 3)$ & $0.11 \pm 0.01 \mathrm{c}$ & $0.72 \pm 0.01 \mathrm{~b}$ \\
FGV $^{\mathrm{v}}$ & $0.07 \pm 0.01 \mathrm{~d}$ & $0.77 \pm 0.01 \mathrm{a}$ \\
FGV+CRH (3:1) & $0.12 \pm 0.01 \mathrm{c}$ & $0.72 \pm 0.01 \mathrm{~b}$ \\
FGV+CRH (1:1) & $0.06 \pm 0.01 \mathrm{~d}$ & $0.67 \pm 0.01 \mathrm{c}$ \\
FGV+CRH (1:3) & $0.02 \pm 0.01 \mathrm{e}$ & $0.48 \pm 0.01 \mathrm{e}$ \\
SB $^{\mathrm{u}}+$ FC $^{\mathrm{t}}(3: 2)$ & $0.19 \pm 0.01 \mathrm{~b}$ & $0.58 \pm 0.01 \mathrm{~d}$ \\
\hline
\end{tabular}

${ }^{z}$ Means ( \pm standard error) followed by the same letter are not significantly different according to a Tukey's test $(\mathrm{p}<0.05) .{ }^{\mathrm{x}} \mathrm{Mecplant}{ }^{\mathrm{B}}$;

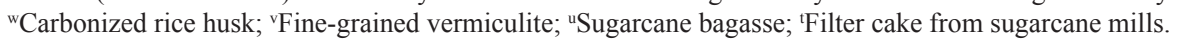

TABLE 3- Stem length (SL), stem diameter (SD), stem length to stem diameter ratio (SL/SD), and number of leaves of Anacardium othonianum Rizz. seedlings at 39, 64, and 89 days after seeding (DAS).

\begin{tabular}{ccccc}
\hline DAS & SL $(\mathrm{cm})$ & SD $(\mathrm{mm})$ & SL/SD $\left(\mathrm{cm} \mathrm{cm}^{-1}\right)$ & Number of leaves \\
\hline 39 & $6.5 \pm 0.3 \mathrm{~b}^{\mathrm{z}}$ & $3.02 \pm 0.1 \mathrm{c}$ & $21.0 \pm 0.7 \mathrm{~b}$ & $5.5 \pm 0.1 \mathrm{c}$ \\
64 & $9.4 \pm 0.3 \mathrm{a}$ & $3.34 \pm 0.1 \mathrm{~b}$ & $27.1 \pm 0.7 \mathrm{a}$ & $6.8 \pm 0.1 \mathrm{~b}$ \\
89 & $10.0 \pm 0.4 \mathrm{a}$ & $3.61 \pm 0.1 \mathrm{a}$ & $27.2 \pm 0 . \mathrm{a}$ & $7.5 \pm 0.1 \mathrm{a}$ \\
\hline
\end{tabular}

${ }^{z}$ Means ( \pm standard error) followed by the same letter are not significantly different according to a Tukey's test $(\mathrm{P}<0.05)$.

TABLE 4 - Stem length (SL), stem diameter (SD), number of leaves (NL), leaf area (LA), leaf dry weight (LDW), stem dry weight (SDW), root dry weight (RDW), and total dry weight (TDW) of Anacardium othonianum Rizz. seedlings grown on different substrates at 89 days after seeding.

\begin{tabular}{|c|c|c|c|c|c|c|c|c|}
\hline \multirow{2}{*}{ Substrate } & \multirow{2}{*}{$\begin{array}{c}\mathrm{SL} \\
(\mathrm{cm})\end{array}$} & \multirow{2}{*}{$\begin{array}{c}\mathrm{SD} \\
(\mathrm{mm})\end{array}$} & \multirow[t]{2}{*}{ NL } & \multirow{2}{*}{$\begin{array}{c}\text { LA } \\
\left(\mathrm{cm}^{2}\right)\end{array}$} & LDW & SDW & RDW & TDW \\
\hline & & & & & \multicolumn{4}{|c|}{$(\mathrm{g})$} \\
\hline Bioplant ${ }^{\circledR}$ & $10.8 \pm 2.1 a^{z}$ & $3.68 \pm 0.4^{\mathrm{y}}$ & $7.2 \pm 0.8^{y}$ & $139.4 \pm 34$ & $0.72 \pm 0.1^{\prime}$ & $0.59 \pm 0.19^{y}$ & $0.63 \pm 0$. & $1.94 \pm 0.46^{\mathrm{y}}$ \\
\hline $\mathrm{MP}^{\mathrm{x}}+\mathrm{CRH}^{\mathrm{w}}(7: 3)$ & $10.2 \pm 2.0 \mathrm{a}$ & $3.69 \pm 0.4$ & $7.6 \pm 0.9$ & $143.2 \pm 34$ & $0.76 \pm 0.13$ & $0.52 \pm 0.15$ & $0.67 \pm 0.13$ & $1.95 \pm 0.39$ \\
\hline $\mathrm{GV}^{\mathrm{v}}$ & $8.7 \pm 1.8 b$ & $3.48 \pm 0.5$ & $6.9 \pm 0.6$ & $107.8 \pm 26$ & $0.62 \pm 0.16$ & $0.48 \pm 0.18$ & $0.53 \pm 0.14$ & $1.63 \pm 0.46$ \\
\hline $\mathrm{FGV}+\mathrm{CRH}(3: 1)$ & $11.2 \pm 2.2 \mathrm{a}$ & $3.70 \pm 0.5$ & $7.8 \pm 0.7$ & $135.2 \pm 32$ & $0.90 \pm 0.25$ & $0.70 \pm 0.22$ & $0.80 \pm 0.20$ & $2.40 \pm 0.64$ \\
\hline $\mathrm{GV}+\mathrm{CRH}(1: 1)$ & $10.6 \pm 2.5 \mathrm{a}$ & $3.73 \pm 0.4$ & $7.5 \pm 0.8$ & $126.2 \pm 34$ & $0.74 \pm 0.22$ & $0.61 \pm 0.19$ & $0.70 \pm 0.19$ & $2.05 \pm 0.57$ \\
\hline $\mathrm{FGV}+\mathrm{CRH}(1: 3)$ & $8.1 \pm 1.2 b$ & $3.28 \pm 0.3$ & $7.6 \pm 0.7$ & $101.0 \pm 21$ & $0.58 \pm 0.14$ & $0.44 \pm 0.10$ & $0.62 \pm 0.13$ & $1.63 \pm 0.32$ \\
\hline $\mathrm{SB}^{\mathrm{u}}+\mathrm{FC}^{\mathrm{t}}(3: 2)$ & $10.0 \pm 1.7 \mathrm{a}$ & $3.72 \pm 0.5$ & $7.6 \pm 0.6$ & $138.6 \pm 32$ & $0.77 \pm 0.19$ & $0.49 \pm 0.14$ & $0.51 \pm 0.13$ & $1.77 \pm 0.44$ \\
\hline
\end{tabular}

${ }^{z}$ Means ( \pm standard error) followed by the same letter are not significantly different according to a Tukey's test ( $\left.<<0.05\right)$. ${ }^{y}$ Means ( \pm standard error) and means are not significantly different according to a Tukey's test $(\mathrm{p}<0.05) ;{ }^{\mathrm{x}} \mathrm{Mecplant}{ }^{\mathbb{\mathbb { }}}$; ${ }^{\mathrm{W}}$ Carbonized rice husk; ${ }^{\vee}$ Fine-grained vermiculite; "Sugarcane bagasse; 'Filter cake from sugarcane mills.

TABLE 5- Root to shoot ratio (R/S), stem length to stem diameter ratio (SL/SD), and the Dickson quality index (DQI) for Anacardium othonianum Rizz. seedlings grown on different substrates.

\begin{tabular}{|c|c|c|c|}
\hline Substrate & $\begin{array}{l}\mathrm{R} / \mathrm{S} \\
\mathrm{g} \mathrm{g}^{-1}\end{array}$ & $\begin{array}{c}\mathrm{SL} / \mathrm{SD} \\
\mathrm{cm} \mathrm{cm}^{-1}\end{array}$ & DQI \\
\hline Bioplant ${ }^{\circledR}$ & $0.55 \pm 0.10^{y}$ & $28.5 \pm 3.3^{y}$ & $0.39 \pm 0.08^{y}$ \\
\hline $\mathrm{MP}^{\mathrm{x}}+\mathrm{CRH}^{\mathrm{w}}(7: 3)$ & $0.55 \pm 0.06$ & $26.8 \pm 3.2$ & $0.43 \pm 0.08$ \\
\hline $\mathrm{FGV}^{\mathrm{v}}$ & $0.51 \pm 0.07$ & $24.8 \pm 3.7$ & $0.36 \pm 0.09$ \\
\hline FGV+CRH(3:1) & $0.55 \pm 0.07$ & $29.4 \pm 3.6$ & $0.48 \pm 0.11$ \\
\hline FGV+CRH(1:1) & $0.61 \pm 0.15$ & $27.0 \pm 4.2$ & $0.42 \pm 0.09$ \\
\hline FGV+CRH(1:3) & $0.64 \pm 0.09$ & $24.1 \pm 2.2$ & $0.40 \pm 0.08$ \\
\hline $\mathrm{SB}^{\mathrm{u}}+\mathrm{FC}^{\mathrm{t}}(3: 2)$ & $0.43 \pm 0.04$ & $27.5 \pm 3.7$ & $0.34 \pm 0.08$ \\
\hline
\end{tabular}

${ }^{\mathrm{y}}$ Means ( \pm standard error) are not significantly different according to a Tukey's test $(\mathrm{p}<0.05) .{ }^{\mathrm{x}}$ Mecplant ${ }^{\mathbb{}} ;{ }^{\mathrm{w}}$ Carbonized rice husk; ${ }^{\mathrm{v} F i n e-}$ grained vermiculite; "'Sugarcane bagasse; 'Filter cake from sugarcane mills. 
TABLE 6- Leaf concentrations of nitrogen $(\mathrm{N})$, phosphorus $(\mathrm{P})$, potassium $(\mathrm{K})$, calcium $(\mathrm{Ca})$, magnesium $(\mathrm{Mg})$, and sulfur(S) in Anacardium othonianum Rizz. seedlings grown on different substrates.

\begin{tabular}{lcccccc}
\hline \multirow{2}{*}{ Substrate } & \multicolumn{2}{c}{$\mathrm{N}$} & $\mathrm{P}$ & $\mathrm{Ca}$ & $\mathrm{Mg}$ & $\mathrm{S}$ \\
\cline { 2 - 7 } Bioplant $^{\circledR}$ & $1.65 \pm 0.05 \mathrm{~b}^{\mathrm{z}}$ & $0.35 \pm 0.04 \mathrm{a}^{\mathrm{z}}$ & $0.83 \pm 0.09 \mathrm{a}^{\mathrm{z}}$ & $0.73 \pm 0.35 \mathrm{~b}^{\mathrm{z}}$ & $0.14 \pm 0.12^{\mathrm{y}}$ & $0.11 \pm 0.01^{\mathrm{y}}$ \\
MP $^{\mathrm{x}}+\mathrm{CRH}(7: 3)$ & $2.03 \pm 0.07 \mathrm{ab}$ & $0.40 \pm 0.04 \mathrm{a}$ & $0.80 \pm 0.07 \mathrm{a}$ & $1.38 \pm 0.41 \mathrm{a}$ & $0.38 \pm 0.01$ & $0.09 \pm 0.02$ \\
FGV & $1.93 \pm 0.23 \mathrm{~b}$ & $0.21 \pm 0.01 \mathrm{~b}$ & $0.52 \pm 0.03 \mathrm{~b}$ & $0.93 \pm 0.10 \mathrm{~b}$ & $0.26 \pm 0.12$ & $0.11 \pm 0.02$ \\
FGV+CRH (3:1) & $1.58 \pm 0.10 \mathrm{~b}$ & $0.18 \pm 0.01 \mathrm{~b}$ & $0.60 \pm 0.04 \mathrm{~b}$ & $0.71 \pm 0.02 \mathrm{~b}$ & $0.27 \pm 0.12$ & $0.09 \pm 0.01$ \\
FGV+CRH (1:1) & $1.82 \pm 0.18 \mathrm{~b}$ & $0.19 \pm 0.01 \mathrm{~b}$ & $0.60 \pm 0.09 \mathrm{~b}$ & $0.76 \pm 0.08 \mathrm{~b}$ & $0.29 \pm 0.12$ & $0.11 \pm 0.01$ \\
FGV+CRH (1:3) & $1.70 \pm 0.12 \mathrm{~b}$ & $0.21 \pm 0.01 \mathrm{~b}$ & $0.53 \pm 0.02 \mathrm{~b}$ & $0.86 \pm 0.09 \mathrm{~b}$ & $0.26 \pm 0.11$ & $0.10 \pm 0.01$ \\
SB+FC (3:2) & $2.47 \pm 0.14 \mathrm{a}$ & $0.35 \pm 0.05 \mathrm{a}$ & $0.75 \pm 0.05 \mathrm{a}$ & $1.82 \pm 0.17 \mathrm{a}$ & $0.36 \pm 0.01$ & $0.10 \pm 0.01$ \\
\hline
\end{tabular}

${ }^{z}$ Means ( \pm standard error) followed by the same letter are not significantly different according to a Tukey's test(p<0.05); ${ }^{\text {Means }}$ ( \pm standard error)are not significantly different according to a Tukey’s test $(\mathrm{p}<0.05)$; ${ }^{\mathrm{x}}$ Mecplant ${ }^{\mathbb{R}}$; ${ }^{\mathrm{w}}$ Carbonized rice husk; ${ }^{\mathrm{v}} \mathrm{Fine}-\mathrm{grained}$ vermiculite; "Sugarcane bagasse; ${ }^{\mathrm{t}}$ Filter cake from sugarcane mills.

TABLE 7- Leaf concentrations of boron (B), copper (Cu), manganese (Mn), zinc $(\mathrm{Zn})$, and iron $(\mathrm{Fe})$ in Anacardium othonianum Rizz. seedlings grown on different substrates.

\begin{tabular}{lccccc}
\hline \multirow{2}{*}{ Substrate } & $\mathrm{B}$ & $\mathrm{Cu}$ & $\mathrm{Mn}$ & $\mathrm{Zn}$ & $\mathrm{Fe}$ \\
\cline { 2 - 6 } & \multicolumn{4}{c}{$\mathrm{mg} \mathrm{g}^{-1}$} \\
\hline Bioplant $^{\circledR}$ & $43.3 \pm 13.0 \mathrm{a}^{\mathrm{z}}$ & $6.27 \pm 0.68^{\mathrm{y}}$ & $65.7 \pm 6.8 \mathrm{~b}^{\mathrm{z}}$ & $28.2 \pm 3.9^{\mathrm{y}}$ & $273.2 \pm 58.1^{\mathrm{y}}$ \\
MP $^{\mathrm{x}}+\mathrm{CRH}^{\mathrm{w}}(7: 3)$ & $42.8 \pm 7.2 \mathrm{a}$ & $4.99 \pm 0.76$ & $159.1 \pm 17.1 \mathrm{a}$ & $24.4 \pm 1.2$ & $186.8 \pm 67.6$ \\
FGV & $15.5 \pm 7.9 \mathrm{~b}$ & $6.19 \pm 0.28$ & $28.8 \pm 3.1 \mathrm{~b}$ & $24.6 \pm 0.9$ & $298.3 \pm 48.1$ \\
FGV+CRH (3:1) & $13.4 \pm 6.5 \mathrm{~b}$ & $6.40 \pm 0.25$ & $31.7 \pm 6.8 \mathrm{~b}$ & $22.6 \pm 0.6$ & $333.8 \pm 80.9$ \\
FGV+CRH (1:1) & $18.8 \pm 7.1 \mathrm{~b}$ & $6.68 \pm 0.53$ & $40.4 \pm 3.1 \mathrm{~b}$ & $25.0 \pm 1.1$ & $275.4 \pm 31.2$ \\
FGV+CRH (1:3) & $19.5 \pm 6.6 \mathrm{~b}$ & $5.88 \pm 0.46$ & $43.2 \pm 6.9 \mathrm{~b}$ & $24.7 \pm 1.0$ & $247.4 \pm 22.6$ \\
SB $^{\mathrm{u}}+\mathrm{FC}^{\mathrm{t}}(3: 2)$ & $22.6 \pm 5.1 \mathrm{~b}$ & $6.04 \pm 0.19$ & $12.1 \pm 1.5 \mathrm{~b}$ & $24.8 \pm 0.5$ & $375.1 \pm 59.5$ \\
\hline
\end{tabular}

${ }^{z}$ Means ( \pm standard error) followed by the same letter are not significantly different according to a Tukey's test ( $\left.<<0.05\right)$; ${ }^{y}$ Means $( \pm$ standard error) are not significantly different according to a Tukey's test ( $<<0.05) ;{ }^{\mathrm{x}}$ Mecplant ${ }^{\circledR}$; ${ }^{\mathrm{w}}$ Carbonized rice husk; ${ }^{\mathrm{v}}$ Fine-grained vermiculite; "Sugarcane bagasse; 'Filter cake from sugarcane mills.

\section{CONCLUSIONS}

Sugarcane agro-industrial residues (sugarcane bagasse and filter cake) are promising materials for use as substrates.

Anacardium othonianum Rizz. seedlings grown on different substrates exhibited equal quality.

Seedlings grown on a substrate of sugarcane bagasse and filter cake had the highest leaf macronutrient levels, followed by those grown on a substrate of Mecplant ${ }^{\circledR}$ with carbonized rice husk and on a substrate of Bioplant ${ }^{\circledR}$.

\section{ACKNOWLEDGEMENTS}

The authors acknowledge CAPES.

\section{REFERENCES}

ARAÚJO NETO, S.E.; AZEVEDO, J.M.A.; GALVÃO, R.O.; OLIVEIRA, E.B.L.; FERREIRA, R.L.F. Produção de muda orgânica de pimentão com diferentes substratos. Ciência Rural, Santa Maria, v.39, n.5, p.1.408-1.413, 2009.

ASSIS, K.C.; PEREIRA, F.D.; ALBERTO, P.S.; SILVA, F.G.; SILVA, J.W.; MENEZES, C.C.E. In vitro cultivation of Anacardium othonianum Rizz. Effects of growth regulator explant orientation and lighting. African Journal of Biotechnology, Nairobi, v.11, n.7, p.1.559-1.566, 2012.

CATUNDA, P.H.A.; MARINHO, C.S.; GOMES, M.M.A.; CARVALHO, A.J.C. Brassinosteroide e substratos na aclimatação do abacaxizeiro 'Imperial' . Acta Scientiarum Agronomy, Maringá, v.30, n3, p.345-352, 2008. 
CORREA, G.C,; NAVES, R.V.; ROCHA, M.R.; CHAVES, L.J.; BORGES, J.D. Determinações físicas em frutos e sementes de baru (Dipteryx alata Vog.), cajuzinho (Anacardium othonianum Rizz.) e pequi (Caryocar brasiliense Camb.), visando ao melhoramento genético. Bioscience Journal, Uberlândia, v.24, n.4, p.42-47, 2008.

CRISÓSTOMO, L.A.; NAUMOV, A. Adubando para alta produtividade e qualidade: fruteiras tropicais do Brasil. Fortaleza: Embrapa Agroindústria Tropical, 2009. 238p.

DANTAS, B.F.; LOPES, A.P.; SILVA, F.F.S. da; LÚCIO, A.A.; BATISTA, P.F.; PIRES, M.M.M. L.; ARAGÃO, C.A. Taxas de crescimento de mudas de catingueira submetidas a diferentes substratos e sombreamentos. Revista Árvore, Viçosa, MG, v.33, n.3, p.413-423, 2009.

De BOODT, M.; VERDONCK, O.; CAPPAERT, I. Method for measuring the water release curve of organic substrates. Acta Horticulturae, Wageningen, v.37, p.2.054-2.062. 1974.

DICKSON, A.; LEAF, A.L.; HOSNER, J.F. Quality appraisal of white spruce and white pine seedling stock in nurseries. Forest Chronicle, Toronto.36, p.10-13, 1960.

FERMINO, M. H.; GONÇALVES, R.S.; BATTISTIN, A.; SILVEIRA, J.R.P.; BUSNELLO, A.C.; TREVISAM, M. Aproveitamento dos resíduos da produção de conserva de palmito como substrato para plantas. Horticultura Brasileira, Vitória da Conquista, v.28, n.3, p.282-286, 2010.

FERRAZ, M.V.; CENTURION, J.F.; BEUTLER, A.N. Caracterização física e química de alguns substratos comerciais. Acta Scientiarum Agronomy, Maringá, v.27, n.2, p. 209-214, 2005.

FERREIRA, D. F. Sisvar: um sistema computacional de análise estatística. Ciência e Agrotecnologia, Lavras, v.35, n.6, p.1.039-1.042, 2011.

FIDALSKI, J.; CHAVES, J.C.D. Resposta do cafeeiro (Coffea arabica L.) IAPAR-59 à aplicação superficial de resíduos orgânicos em um Latossolo Vermelho distroférrico típico. Coffee Science, Lavras, v.5, n.1, p.75-86. 2010.
GOMES, J.M.; COUTO, L.; LEITE, H.G.; XAVIER, A.; GARCIA, S.L.R. Parâmetros morfológicos na avaliação da qualidade de mudas de Eucaliptus grandis. Revista Árvore, Viçosa, MG, v.26, n.6, p.655-664, 2002.

GRIGATTI, M.; GIORGIONI, M.E.; CIAVATTA, C. Compost-based growing media: influence on growth and nutrient use of bedding plants. Bioresource Technology, Essex, v.98, p.3.526-3.534, 2007.

MAGUIRE, J.D. Speed of germination aid in selection and evaluation for seedling and vigour. Crop Science, Madison, v.2, n.2, p.176-177, 1962.

MALAVOLTA, E.; VITTI, G.C.; OLIVEIRA, S.A. Avaliação do estado nutricional das plantas: princípios e aplicações. 2. ed. Piracicaba: Associação Brasileira para Pesquisa do Potássio e do Fosfato, 1997. 319p.

MATHERS, H.M.; LOWE, S.B.; SCAGEL, C.; STRUVE, D.K.; CASE, L.T. Abiotic factors influencing growth of woody nursery plants in containers. Hort Technology, Alexandria, v.17, n.2, p.151-162, 2007.

NOGUEIRA, R.J.M.C.; ALBUQUERQUE, M.B.; SILVA JÚNIOR, J.F. Efeito do substrato na emergência, crescimento e comportamento estomático em plantas de mangabeira. Revista Brasileira de Fruticultura, Jaboticabal, v.25, n.1, p.15-18, 2003.

ROSA, M. E. C. da; NAVES, R. V.; OLIVEIRA JÚNIOR, J. P. de. Produção e crescimento de mudas de mangabeira (Hancornia speciosa Gomes) em diferentes substratos. Pesquisa Agropecuária Tropical, Goiânia, v.35, n.2, p.65-70, 2005.

SAIDELLES, F.L.F.; CALDEIRA, M.V.W.; SCHIRMER, W.N.; SPERANDIO, H.V. Casca de arroz carbonizada como substrato para produção de mudas de tamboril-da-mata e garapeira. Semina: Ciências Agrárias, Londrina, v.30, supl. 1, p.1.1731.186, 2009.

SANTANA, C.T.C.; SANTI, A.; DALLACORT, R.; SANTOS, M.L.; MENEZES, C.B. Desempenho de cultivares de alface-americana em resposta a diferentes doses de torta de filtro. Revista Ciência Agronômica, Fortaleza, v.43, n.1, p.22-29, 2012. 
SILVA, E.A.; MARUYAMA, W.I.; OLIVEIRA, A.C.; BARDIVIESSO, D.M. Efeito de diferentes substratos na produção de mudas de mangabeira (Hancornia speciosa). Revista Brasileira de Fruticultura, Jaboticabal, v.31, n.3, p.925-929, 2009.

SILVA, M.R.; LACERDA, B.C.L.; SANTOS, G.G.; MARTINS, D.M.O. Caracterização química de frutos nativos do cerrado. Ciência Rural, Santa Maria, v.38, p.1.790-1.793, 2008.
SOUZA, O.A.; NASCIMENTO, J.L.; NAVES, R.V.; BORGES, J.D. Propagação sexuada de pequizeiro (Caryocar brasiliense (Camb.): efeito da procedência de frutos e do ácido giberélico na emergência de plântulas. Pesquisa Agropecuária Tropical, Goiânia, v.37, n.3, p.131-136, 2007.

TERRA, S.B.; FERREIRA, A.A.F.; PEIL, R.M.N.; STUMPF, E.R.T.; BECKMANN-CAVALCANTE, M.Z.; CAVALCANTE, I. H.L. Alternative substrates for growth production of potted chrysanthemum (cv. Funny). Acta Scientiarum Agronomy, Maringá, v.33, n.3, p.465-471, 2011. 